\title{
Великое княжество Финляндское в составе Российской империи в начале XX в.: по материалам журнала «Финляндия»
}

\author{
Карнишина Н.Г., Карнишин В.Ю. \\ Пензенский государственный университет, \\ Россия, 440026, г. Пенза, улица Красная, 40 \\ E-mail:karnishins@mail.ru, valerykarnishin@mail.ru
}

\begin{abstract}
Аннотация. Статья посвящена исследованию проблем взаимодействия имперских властей и местного сообщества Великого княжества Финляндского в начале XX века через призму трактовок современниками, что нашло свое отражение в полемике на страницах журнала «Финляндия» в 1908-1910 гг. Авторы данного издания посвящали свои статьи таким вопросам, как положение Финляндии в составе Российской империи, окраинная политика российских властей в отношении княжества. Одной из ключевых проблем национальной политики позднеимперской России являлась необходимость выработки единой модели управления окраинами, опираясь на принцип этноцентризма на базе сложившихся национальногосударственных традиций. Расхождения во взглядах русских и финских государственных и общественных деятелей и публицистов были связаны с решением вопроса о переходе от имперского к национальному принципу имперской политики на окраинах, что в первую очередь относилось к западным губерниям Российской империи начиная со второй половины XIX века. Автономный статус Финляндии предопределял перевес именно национального принципа окраинной политики над имперским.
\end{abstract}

Ключевые слова: окраины государства, национальная политика Российской империи, периодическая печать, областная автономия.

Для цитирования: Карнишина Н.Г., Карнишин В.Ю. Великое княжество Финляндское в составе Российской империи в начале XX в.: по материалам журнала «Финляндия». Via in tempore. История Политология. 48 (4): 849-858. DOI: 10.52575/2687-0967-2021-48-4-849-858.

\section{Grand Duchy of Finland in the Russian Empire at the beginning of the XX century: on the publications of the magazine «Finland»}

\author{
Natalia G. Karnishina, Valery Yu. Karnishin \\ Penza State University, \\ 40 Krasnaya St., Penza 440026, Russia \\ E-mail: karnishins@mail.ru, valerykarnishin@mail.ru
}

\begin{abstract}
In this article authors investigate the problems of interaction and relationship between the imperial authorities and the local community of the Grand Duchy of Finland at the beginning of the XX century in the publications of contemporaries, which was reflected in the polemics on the pages of the magazine «Finland» in 1908-1910. The authors of this publication devoted their articles to such issues as the situation of Finland within the Russian Empire, the policy of the Russian authorities in remote parts in relation to the centre of empire. The most important problem of the national policy of late Imperial Russia was the need to develop a unified model of management of the remote parts, based on the principle of ethnocentrism on the basis of established national and state traditions. The differences in the views of Russian and Finnish statesmen and public figures and publicists were connected with the decision on the transition from the imperial to the national principle of imperial policy on the outskirts, which, first of all, related to the remote parts of the Russian Empire, starting from the second half of the XIX century. The
\end{abstract}


autonomous status of Finland predetermined the preponderance of the national principle of marginal politics over the imperial one.

Keywords: margins of the state, national policy of the Russian Empire, periodical press, regional autonomy.

For citation: Karnishina N.G., Karnishin V.Yu. Grand Duchy of Finland in the Russian Empire at the beginning of the XX century: on the publications of the magazine «Finland». Via in tempore. History and political science. 48 (4): 849-858 (in Russian). DOI: 10.52575/2687-0967-2021-48-4-849-858.

\section{Введение}

Вопросам управления Великим княжеством Финляндским, истории российскофинляндских отношений, а также правовому положению данной территории в составе Российской империи в XIX - начале XX вв. посвящен ряд исследований отечественных и зарубежных авторов [Могунова, 2005; Оссио, 2009; Карнишина, 2010; Миллер, 2010; Неземанн, 2015; Ковальов, 2017; Куликов, 2017; Weeks, 1996; Nygård, 2003].

Цель данной статьи - на основе материалов периодической печати, мемуарной литературы провести анализ восприятия современниками сущности и особенностей имперской политики на национальных окраинах Российской империи на протяжении конца XIX - начала XX вв. на примере положения Великого княжества Финляндского.

Отношение местного сообщества к русскоязычному населению, статус государственного языка, проблема русификации, процесс насаждения административных институтов по имперскому образцу - все эти вопросы поднимали авторы публикаций. В имперском измерении российской истории историография проблемы была посвящена исследованию административно-политических и правовых структур империи, а также внешнеполитического фактора в разрезе национальной политики Российской империи. Несмотря на наличие ряда статей, посвященных анализу образа Финляндии периода нахождения в составе Российской империи в русской периодической печати [Жабоедов-Господарец, 2013; Новикова, 2014], авторы не использовали публикации в журнале «Финляндия» как источник для исследования взглядов современников на аспект взаимодействия имперской власти и финского общества. Наиболее полный историографический анализ статуса окраин Российской империи именно в разрезе государственного управления и национальной политики представлен в монографии А.Ю. Бахтуриной [Бахтурина, 2004].

\section{Объекты и методы исследования}

Использованы сравнительно-исторический и статистический методы исторического исследования. Исследование проведено на материалах периодической печати, в частности это материалы журнала «Финляндия», обозначенного издателями как «литературный популярный журнал политической и общественной жизни Финляндии», который издавался в Санкт-Петербурге в 1908-1910 гг.

\section{Результаты и их обсуждение}

\section{Полемика на страницах журнала «Финляндия» в 1908-1910 гг.}

Проблема нахождения Финляндии в составе Российской империи в начале XX вв. привлекала внимание не только историков, государствоведов, но и публицистов того периода по многим причинам, в том числе неурегулированным правовым положением присоединенной территории.

Факт присоединения Финляндии к России был закреплен Фридрихсгамским мирным договором, заключенным 5 (17) сентября 1809 г. между шведским королем Карлом XIII и Российским императором Александром I, по которому Российская империя приняла 
обязательство не менять старые государственные институты Финляндии, шведскую конституцию, шведский язык в качестве государственного и не назначать в Финляндию русских чиновников, за исключением своего представителя - генерал-губернатора, который, как правило, шведским языком не владел, что существенно ограничивало его возможности управления данной территорией.

Многие документы, закрепляющие особый статус Финляндии, воспринимались как номинальные и были продиктованы, в частности, тем фактом, что «все делопроизводство в княжестве велось на шведском языке» [Бородкин, 1905, с. 8].

Император четко выразил свое намерение сохранить государственный строй и национальное законодательство Финляндии [Акты для выяснения политического положения ... 1908, с. 5]. Тот факт, что Финляндия сохраняла все основы национального государственного устройства, и стал исходной точкой для последующей полемики по поводу статуса данной территории в составе империи.

Финляндские юристы на протяжении всего XIX века исходили из трактовки статуса Финляндии не как одной из провинций, а как территории, наделенной широкой автономией [Лундаль, 1857; Мехелин, 1888; Заключение по проекту..., 1891; ДаниельсонКальмари, 1892; Нюгольм, 1901; Некрасов, 2010].

М. Могилянский в статье «Финляндский вопрос в правовом освещении (по поводу брошюры Л. Мехелина и к вопросу о ближайшем определении правовых отношений между Россией и Финляндией)», опубликованной в журнале «Финляндия» в октябре 1909 г., писал: «Александр II при утверждении сеймового устава в 1869 г. и Александр III при пересмотре его в 1886 г. в ясных выражениях подтвердили, что правовым основанием прерогативы монарха в Финляндии является форма правления 1772 г. и Акт Соединения и Охранения 1789 г. Наконец, и в настоящее время в текущей государственной жизни Финляндии правительственная власть на каждом шагу осуществляет мероприятия, всецело основанные на вышеупомянутых конституционных актах шведского времени и в спорных случаях прямо ссылается на те или иные параграфы Формы Правления, как это, например, было в январе текущего года при временном продлении взимания ранее утвержденных налогов» [Могилянский, 1909].

Ряд русских государствоведов в отношении определения статуса Финляндии исходил из теории союзного государства, а именно союза государств, подчеркивая, что в данном случае имеет место пример предоставления широкой автономии отдельному княжеству.

Например, А. Романович-Словатинский доказывал, что Финляндия «не инкорпорирована, но находится в унии с Империей, в унии реальной, но не личной, т. к. они связаны неразрывно» [Романович-Словатинский, 1886]. В данном случае мы видим прямой отказ автора считать княжество одной из провинций Российской империи.

Отчасти данный подход разделял Б.Н. Чичерин, который исходил из того факта, что Финляндия присоединена к России не как завоеванная область, а как «отдельное государство, неразрывно связанное с Россией, но имеющее свою особенную конституцию» [Чичерин, 1894].

Ф. Кокошкин в 1910 г. подвел итог полемике финских и русских государственных и общественных деятелей, утверждая, что на вопрос о том, может ли быть юридическое положение Финляндии изменено без согласия ее законодательных учреждений, подавляющее большинство юристов даст отрицательный ответ.

В подтверждение данного тезиса автор приводит выдержку из Манифеста 9 февраля 1816 г. «О переименовании императорского правительствующего совета в императорский финляндский Сенат», в котором говорится, что «...конституция и законы, к обычаям, образованию и духу финляндского народа примененные и с давних пор положившие основания гражданской его свободы и устройству, не могут быть ограничиваемы и отменены без нарушения оных. Мы при восприятии царствования над сим краем не только тор- 
жественнейше утвердили конституцию и законы сии с прилегающими на основании оных каждому финляндскому согражданину особенными правами и преимуществами, но, по предварительном рассуждении о сем с собравшимися земскими края сего чинами, и учредили особенное правительство под названием правительствующего совета, состоящего из коренных финляндцев, которой доселе управлял гражданской частью края сего и решал судебные дела в качестве последней инстанции, не зависев ни от какой другой власти, кроме власти законов и сообразующейся с оными монаршей нашей воли» [Кокошкин, 1910, c. 378].

Царское правительство в конце XIX в. предприняло попытку установить в Финляндии общероссийское законодательство. Так, Указ 1899 г. предусматривал применение в Финляндии общероссийского законодательства, если тот или иной вопрос «затрагивал общероссийские интересы». Данные изменения объясняют рост интереса общественных кругов России и Финляндии к этой проблеме.

Погодин А.Л. в статье «Финляндия и Польша» так оценивал положение дел: «Если уже в конце минувшего царствования подготовлялись меры, имевшие целью разрешить спорный вопрос о юридическом положении Великого Княжества Финляндского в духе русской автократии, то все же лишь с 1899 г. начинается вполне определенная политика уничтожения конституционных форм в этой стране. Логический ход мыслей, который приводил к отрицанию финляндской конституции, совершенно ясен: он обнаружился и в 1869 г., когда финляндцам не удалось получить свободу печати, и в начале $1890-$ х гг., когда в новом уголовном уложении Великого Княжества заметили слишком легкое отношение к политическим преступлениям. Финляндия должна была лишиться тех прав, которые стояли в слишком резком противоречии с нормами, привычными и излюбленными правительством в России» [Погодин, 1909, с. 13].

Принятие Правил 20 мая 1908 г. «О порядке направления финляндских дел, касающихся интересов империи» дало толчок дискуссии финляндских и русских государственных деятелей и на страницах периодических изданий, и в стенах Государственной Думы.

Ф. Кокошкин откликнулся на эти события обстоятельной публикацией в журнале «Финляндия» [Кокошкин, 1909]. Он писал: «Что же до затяжного кризиса в русскофинляндских отношениях, свидетелями которого мы являемся в настоящее время, то наиболее значимым событием, определяющим его характер, нужно признать, несомненно, правила 20 мая 1908 г. Правила эти, которые в Финляндии не без основания сравнивают с Манифестом 3 февраля 1899 г., ибо они действительно проводят в области финляндского верховного управления те же начала, которые данный манифест проводил в области законодательства, не явились совершенно неожиданными. Уже в 1907 г. и в июне 1908 г., и вопреки установленному порядку доклада финляндских законодательных и правительственных дел через финляндские органы, некоторые из таких дел восходили на Высочайшее разрешение через Совет министров».

Автор статьи привел отрывок из речи П.А. Столыпина в Государственной Думе, по смыслу которого: «...внутренняя самостоятельность Финляндии, гарантированная утвержденной Александром I конституцией, простирается исключительно на внутренние финляндские дела, но не на отношения ее и России на их «общие» дела Империи и Великого княжества, к которым и относятся Правила 20 мая. Дела общие России и Финляндии - это международные сношения и внешнее управление, поскольку оно не касается предметов сеймового законодательства и финансового хозяйства Финляндии. Совет министров приобретает право определять свою собственную компетенцию в области, выходящей из подлинного круга его ведомств, и тем самым определять и компетенцию имперской власти в сфере законодательства и управления автономией страны. В руки этого органа переходит компетенция, которая считает неотъемлемой принадлежностью и характерным признаком суверенитета власти». Следует отметить, что данная речь П.А. Столыпина вызвала широ- 
кий общественный резонанс ввиду того, что в ней, по сути, провозглашается распространение имперского законодательства на Великое княжество Финляндское.

Сословно-представительный Сейм рассматривался в Финляндии как главный орган защиты интересов населения. Сейм начиная с 1863 г. принял целый ряд законов, с помощью которых осуществлялись широкие преобразования в государственной жизни Финляндии.

Интересна позиция П. Ренвалла, который связывал принятие Сеймового устава в 1869 г. с принятием нового церковного закона. Тем самым, по его мнению, новый Сеймовый устав способствовал «...устройству общинной представительной системы и реорганизации представительных собраний в лютеранской церкви Финляндии» [Ренвалл, 1969, c. 14-15].

Сейм в таком виде сохранялся до 1906 г., когда Николай II подписал Сеймовый устав, которым предусматривалось образование однопалатного Сейма, избираемого на основе всеобщего и прямого избирательного права. Впервые в Европе избирательные права получили женщины Финляндии.

В статье «История одной юридической теории Совета министров» С. Корф довольно резко критиковал новую редакцию Сеймового устава. В частности, он писал: «Зимой этого года Совет министров устроил маленький сюрприз юристам-государственникам, выпустив в свет своей теории о ничтожности актов распущенного законодательного собрания, в частности, эта теория была направлена против строптивых финляндцев и их сейма, гласила же она, что всякий акт распущенного сейма его ipso теряет всякую силу и значение. Центр тяжести теперь перенесен на благоусмотрение Монарха, который может в виде наказания распускать сейм и объявить его акты ничтожными» [Корф, 1909, 141]. Автор статьи доказывал, что таким подходом Петербург разрушает основы особого статуса княжества и подрывает доверие к имперским властям.

По поводу новой редакции Сеймового устава Ф.Ф. Кокошкин на страницах журнала «Финляндия» детально останавливался на анализе модели государственного управления княжеством в позднеимперский период, подвергая довольно резкой критике предпринятые царским правительством меры по ограничению автономии княжества. В частности, он писал: «На основании заключения Совета министров 24 марта 1908 г. был распущен первый финляндский сейм, избранный путем всеобщего голосования. Правила 20 марта 1906 г. коренным образом изменяют установленный ранее порядок. Согласно первому пункту их «суждения о том, какие из возникающих по Великому Княжеству Финляндскому дел затрагивают вместе с тем и интересы Империи и посему возлагаются на совет министров». Соответственно этому в следующих пунктах устанавливается, что все законодательные и важнейшие административные дела (пределы управления) одновременно с передачей их министру статс-секретарю Финляндии сообщаются в копиях на предварительный просмотр совета министров, и без заключения последнего дело не может быть доложено Государю Императору. Приведенные правила были встречены в Финляндии как ограничения установленной финляндской конституцией внутренней автономии края» [Кокошкин, 1909].

Как видно из приведенных цитат, авторы журнала «Финляндия» неоднократно критиковали решения правительства Николая II по ограничению законодательной компетенции сейма и подтверждению верховных прав императорской власти на Финляндию. Стоит упомянуть в этой связи и генерал-губернатора Финляндии Н.И. Бобрикова, проводившего курс на ограничение автономии Великого княжества, чья политика нередко подвергалась критике авторами на страницах журнала «Финляндия».

Ф.Ф. Кокошкин выразил свое отношение к проводимой администрацией Николая II политике в отношении Финляндии следующим образом: «Целая страна, правда, небольшая, но своеобразная и обособленная в национальном, культурном и правовом отношении, имеющая свою особую конституцию, свое особенное правительство, как бы поступа- 
ет в специальное коллегиальное ведение высшего правительственного учреждения огромной империи, учреждения, которое в силу существующей в этой империи бюрократической централизации загружено и без того заведомо необозримым множеством разнообразнейших дел» [Кокошкин, 1909, с. 59].

В журнале «Финляндия» нашла отражение и такая важная составляющая проблемы окраинной политики Российской империи, как положение русских граждан в Великом княжестве Финляндском.

В 1908 г. в первом номере в редакционной колонке была опубликована статья «О правах русских в Финляндии (в освещении финляндских юристов)». Редактор писал: «За последнее время много говорилось и писалось редакционным органом печати о правовом положении русских в Финляндии, проводились сравнения с теми правами, которые принадлежали финляндским гражданам в империи и даже высказывалось пожелание приравнения финляндцев, проживающих в империи, к иностранцам. При сравнении прав русских в Финляндии и финляндцев в России действительно обнаруживаются существенные различия, заключающиеся в том, что финляндцы, перешедшие на жительство в империю, приобретают в ней все те права, которыми пользуются русские уроженцы, и притом без особого акта приобретения русского гражданства, тогда как русские в Великом Княжестве Финляндском почти во всех отношениях приравнены к иностранцам и лишь посредством натурализации могут приобрести те же права, как и финляндцы».

Вывод автор публикации сформулировал предельно категорично: «Русские подчинены действиям правительственной власти и законов Империи, финляндцы не подчинены правительственной власти и законам Великого Княжества. Исходя из этого положения Финляндия имеет полное право требовать, чтобы приобретение всех прав финляндских уроженцев для лиц, переселяющихся в Великое Княжество из других стран, обуславливалось переходом в финляндское гражданство» [Финляндия, 1908].

По поводу положения финского населения в составе Российской империи автор публикации приводит цитату Р. Германсона: «Не может противоречить интересам России, чтобы народ, населяющий эту часть территории Российского государства, пользовался свободным развитием и не чувствовал себя покоренным народом или смотрел на себя как на средство для удовлетворения интересов другой нации [Финляндия, 1910, с. 16].

По сути, в редакционной статье выражена позиция журнала в понимании автономии Финляндии на уровне государства в государстве.

Рубеж XIX-XX вв. стал переломным для имперских властей в определении подходов к окраинной политике на фоне возрастания межнациональных противоречий. Попытки преодоления изоляции Финляндии путем правовой, административной и экономической интеграции княжества потерпели крах. Юристы, политики и общественные деятели России и Финляндии констатировали на страницах журнала «Финляндия», что юридическое положение Великого княжества оставалось неотрегулированным и неопределенным и выходило за пределы общей национальной окраинной политики империи.

\section{Заключение}

В центре внимания публицистов, государственных и общественных деятелей начала $\mathrm{XX}$ в. были различные аспекты административного, правового, межкультурного взаимодействия в контексте национальной политики Российской империи. Авторы приводят позиции представителей местных локальных сообществ на проблемы языковой, этноконфессиональной политики империи.

На всем протяжении пребывания Финляндии в составе Российской империи в XIX - начале XX вв. создавались обстоятельства, способствующие возникновению противоречий и недовольства со стороны местной элиты. При этом законодательство в отношении Финляндии конца XIX - начала XX вв. не нарушало основ автономного статуса 
территории. Материалы журнала «Финляндия» 1908-1910 гг. достаточно полно отражали спектр взглядов на данную проблему, показывая через призму отношения к финляндской конституции позиции различных государственных и общественных деятелей, в том числе депутатов Государственной Думы, П.А. Столыпина, а также представителей партии октябристов к окраинной политике в целом и к статусу Финляндии в частности.

\section{Список литературы}

1. Акты для выяснения политического положения Великого княжества Финляндского. 1908. СПб., Изд. Г. Борениус, 86

2. Бахтурина А.Ю. 2004. Окраины Российской империи: государственное управление и национальная политика в годы Первой мировой войны (1914-1917 гг.). М., Российская политическая энциклопедия (РОССПЭН), 392.

3. Бородкин М.М. 1905. Из новейшей истории Финляндии. Время управления Н.И. Бобрикова. СПб., Т-во 3. Голике А. Вильборг, 482.

4. Жабоедов-Господарец В.П. 2013. Характеристика правового статуса Великого княжества Финляндского по материалам периодической печати начала XX столетия / В.П. ЖабоедовГосподарец. Известия высших учебных заведений. Поволжский регион. Гуманитарные науки. № 1 (25): $17-31$.

5. Заключение по проекту основных законов Великого Княжества Финляндского: «формы правления» и «сословных привилегий», выработанному Особым, учрежденным по высочайшему повелению 9/21 марта 1885 г. комитетом в г. Гельсингфорсе. Санкт-Петербург, 1891, 100.

6. Карнишина Н.Г. 2010. Статус Великого княжества Финляндского в составе Российской империи в оценках дореволюционных ученых-юристов. История государства и права, 15: 24-28.

7. Ковальов Д.В. 2017. Зарождение и развитие свекоманской оппозиции в Великом княжестве Финляндском. Вестник Омского университета. Серия: Исторические науки, 2 (14): 28-35. $139-141$.

8. Корф С.А. 1909. История одной юридической теории Совета министров. Финляндия. 8:

9. Кокошкин Ф.Ф. 1909. Правила 20 мая 1908 г. «О порядке направления финляндских дел». Финляндия. 5: 21-29.

10. Кокошкин Ф.Ф. 1910. Правила 20 мая 1908 г. «О порядке направления финляндских дел». Финляндия. 1: 377-382.

11. Куликов С.В. 2017. Бюрократическая элита Российской империи и Великое княжество Финляндское в 1905-1906 гг.: дискуссии о государственно-правовом статусе Финляндии при подготовке Основных государственных законов. Санкт-Петербургский исторический журнал. 1: $126-141$.

12. Лундаль Б. Руководство к законам Великого княжества Финляндии. Сост. Б. Лундаль. Гельсингфорс: тип. насл. вдовы Симелиус. 1857. VIII, 88.

13. Мехелин Л.Г. 1888. Конституция Финляндии в изложении местного сенатора Л. Мехелина. Precis du droit public du grand duché de Finlande. Par. L. Mechelin, membre du Sénat impérial de Finlande, ancien prof. de droit à l'Université d'Helsingfors; Пер. и доп. примеч. по рус. документам К. Ординым. СПб., Тип. И.Н. Скороходова, 156.

14. Миллер А.И. 2010. Империя Романовых и национализм: Эссе по методологии исторического исследования. М., Новое литературное обозрение, 320.

15. Могунова М.А. 2005. Государственное право Финляндии. М., ОАО «Издательский Дом Городец», 368.

16. Могилянский М.М. 1909. В статье «Финляндский вопрос в правовом освещении (по поводу брошюры Л. Мехелина и к вопросу о ближайшем определении правовых отношений между Россией и Финляндией)». Финляндия. 17: 543-547.

17. Неземанн Ф. 2015. От завоевания к автономии: Политические и государственноправовые причины особого положения Финляндии в Российской империи. Ф. Неземанн. Русский Сборник: исследования по истории России. Ред.-сост. О.Р. Айрапетов, М.А. Колеров, Брюс Меннинг, Пол Чейсти. T. XVII: Финляндия и Россия. М., Модест Колеров, 2015: 113-143. 
18. Некрасов Е.В. 2010. Вопрос о государственно-правовом статусе Великого княжества Финляндского в составе Российской империи в дореволюционной отечественной историкоправовой мысли. Вестник Омского университета. Омск, Изд-во ОмГУ, 1: 53-61.

19. Новая книга о финляндском вопросе (Германсон Р. По вопросу о положении Финляндии. Гельсингфорс, 1909). Автор А. В. Финляндия. 1910. 10: 377-382.

20. Новикова И. 2014. «Пороховой склад», «притон для революционеров», «плацдарм для террористов»: образ Финляндии в российской националистической печати (вторая половина XIX начало XX в.). Финляндия и Россия: образы общего прошлого: Finland and Russia: images of the shared past: сборник научных статей. Междисциплинарный научно-образовательный центр прибалтийско-финских исслед. FENNICA; сост. и науч. ред.: И.Р. Такала, А.В. Толстиков. Петрозаводск, Изд-во ПетрГУ, 2014: 189-198.

21. Нюгольм К.В. 1901. Положение Финляндии в Российской державе: К.В. Нюгольм. Берлин: кн. маг. Штура (владелец И. Реде), 1901. VI, [2]: 125.

22. Оссио Ю. 2009 Великое княжество Финляндское 1809-1917. Перевод с финского языка. Хельсинки: Ruslania Books Oy, 2009, 860.

23. Погодин А.Л. 1909. Финляндия и Польша. Финляндия. 5 (23): 13-16.

24. Ренвалл П. 1969. Семьсот лет народного представительства в Финляндии. Парламент Финляндии. Поорво-Хельсинки: 14-15.

25. Oivo Nygård. 2003. Autonomian menetys. Itsenäisyyden sarastus. Teoksessa: Zetterberg, S. (toim.) Suomen historian pikkujättiläinen: 566-580.

26. Weeks Th.R. 1996. Nations and State in late Imperial Russia. Nationalism and russification on the Western Frontier, 1863-1914. DeKalb, Nothern Illinois University Press, 216.

\section{References}

1. Akty dlya vyyasneniya politicheskogo polozheniya Velikogo knyazhestva Finlyandskogo [Acts to clarify the political situation of the Grand Duchy of Finland]. 1908. SPb., Izd. G. Borenius, 86.

2. Bakhturina A.Yu. 2004. Okrainy Rossiyskoy imperii: gosudarstvennoe upravlenie i natsional'naya politika v gody Pervoy mirovoy voyny (1914-1917 gg.) [Outskirts of the Russian Empire: State Administration and National Policy during the First World War (1914-1917)]. M., Rossiyskaya politicheskaya entsiklopediya (ROSSPEN), 392.

3. Borodkin M.M. 1905. Iz noveyshey istorii Finlyandii. Vremya upravleniya N.I. Bobrikova [From the recent history of Finland. Time management N.I. Bobrikov]. SPb., T-vo Z. Golike A. Vil'borg, 482.

4. Zhaboedov-Gospodarets V.P. 2013. Kharakteristika pravovogo statusa Velikogo knyazhestva Finlyandskogo po materialam periodicheskoy pechati nachala XX stoletiya [Characteristics of the legal status of the Grand Duchy of Finland based on materials from periodicals of the early XX century]. V.P. Zhaboedov-Gospodarets. Izvestiya vysshikh uchebnykh zavedeniy. Povolzhskiy region. Gumanitarnye nauki. № 1 (25): 17-31.

5. Zaklyuchenie po proektu osnovnykh zakonov Velikogo Knyazhestva Finlyandskogo: «formy pravleniya» i «soslovnykh privilegiy» vyrabotannomu Osobym, uchrezhdennym, po vysochayshemu poveleniyu 9/21 marta $1885 \mathrm{~g}$., komitetom v g. Gel'singforse [Conclusion on the draft of the basic laws of the Grand Duchy of Finland: «forms of government» and «estate privileges» developed by the Special, established by the highest order on March 9/21, 1885, by a committee in the city of Helsingfors]. SanktPeterburg, 1891, 100.

6. Karnishina N.G. 2010. Status Velikogo knyazhestva Finlyandskogo v sostave Rossiyskoy imperii v otsenkakh dorevolyutsionnykh uchenykh-yuristov [The status of the Grand Duchy of Finland within the Russian Empire in the assessments of pre-revolutionary scholars-lawyers]. Istoriya gosudarstva i prava, 15: 24-28.

7. Koval'ov D.V. 2017. Zarozhdenie i razvitie svekomanskoy oppozitsii v Velikom knyazhestve Finlyandskom [The origin and development of the svekoman opposition in the Grand Duchy of Finland. Omsk University Bulletin]. Vestnik Omskogo universiteta. Seriya: Istoricheskie nauki, 2 (14): 28-35.

8. Korf S.A. 1909. Istoriya odnoy yuridicheskoy teorii Soveta ministrov [The History of a Legal Theory of the Council of Ministers]. Finlyandiya. 8: 139-141.

9. Kokoshkin F.F. 1909. Pravila 20 maya 1908 g. «O poryadke napravleniya finlyandskikh del» [Regulations on May 20, 1908 «On the procedure for the direction of Finnish affairs»]. Finlyandiya. 5: 21-29. 
10. Kokoshkin F.F. 1910. Pravila 20 maya 1908 g. O poryadke napravleniya finlyandskikh del [Regulations on May 20, 1908 «On the procedure for the direction of Finnish affairs»]. Finlyandiya. 1: 377-382.

11. Kulikov S.V. 2017. Byurokraticheskaya elita Rossiyskoy imperii i Velikoe knyazhestvo Finlyandskoe v 1905-1906 gg.: diskussii o gosudarstvenno-pravovom statuse Finlyandii pri podgotovke Osnovnykh gosudarstvennykh zakonov [The bureaucratic elite of the Russian Empire and the Grand Duchy of Finland in 1905-1906: discussions about the state and legal status of Finland in the preparation of the Basic State Laws]. Sankt-Peterburgskiy istoricheskiy zhurnal. 1: 126-141.

12. Lundal', Bir'er Rukovodstvo k zakonam Velikogo knyazhestva Finlyandii [Lundal, Birier Guide to the laws of the Grand Duchy of Finland]. Sost. B. Lundal'. Gel'singfors: tip. nasl. vdovy Simelius. 1857. VIII, 88.

13. Mekhelin L.G. 1888. Konstitutsiya Finlyandii v izlozhenii mestnogo senatora L. Mekhelina. Precis du droit public du grand duché de Finlande [Constitution of Finland as presented by the local senator L. Mechelin]. Par. L. Mechelin, membre du Sénat impérial de Finlande, ancien prof. de droit à l'Université d'Helsingfors; Per. i dop. primech. po rus. dokumentam K. Ordinym. SPb., Tip. I.N. Skorokhodova, 156.

14. Miller A.I. 2010. Imperiya Romanovykh i natsionalizm: Esse po metodologii istoricheskogo issledovaniya [The Romanov Empire and Nationalism: Essays on the Methodology of Historical Research]. M., Novoe literaturnoe obozrenie, 320.

15. Mogunova M.A. 2005. Gosudarstvennoe pravo Finlyandii [State Law of Finland]. M., OAO «Izdatel'skiy Dom Gorodets», 368.

16. Mogilyanskiy M.M. 1909. V stat'e «Finlyandskiy vopros v pravovom osveshchenii (po povodu broshyury L. Mekhelina i k voprosu o blizhayshem opredelenii pravovykh otnosheniy mezhdu Rossiey i Finlyandiey)» [In the article «The Finland question in legal coverage (concerning L. Mechelin's brochure and the question of the nearest definition of legal relations between Russia and Finland)»]. Finlyandiya. 17: 543-547.

17. Nezemann F. 2015. Ot zavoevaniya k avtonomii: Politicheskie i gosudarstvenno-pravovye prichiny osobogo polozheniya Finlyandii v Rossiyskoy imperii [From conquest to autonomy: Political and state-legal reasons for the special position of Finland in the Russian Empire. F. Nesemann. Russian Collection: research on the history of Russia]. F. Nezemann. Russkiy Sbornik: issledovaniya po istorii Rocsii. Red.-sost. O.R. Ayrapetov, M.A. Kolerov, Bryus Menning, Pol Cheysti. T. XVII: Finlyandiya i Rossiya. M., Modest Kolerov, 2015: 113-143.

18. Nekrasov E.V. 2010. Vopros o gosudarstvenno-pravovom statuse Velikogo knyazhestva Finlyandskogo $\mathrm{v}$ sostave Rossiyskoy imperii $\mathrm{v}$ dorevolyutsionnoy otechestvennoy istoriko-pravovoy mysli [The issue of the state and legal status of the Grand Duchy of Finland within the Russian Empire in pre-revolutionary domestic historical and legal thought]. Vestnik Omskogo universiteta. Omsk, Izd-vo OmGU, 1: 53-61.

19. Novaya kniga o finlyandskom voprose (Germanson R. Po voprosu o polozhenii Finlyandii. Gel'singfors, 1909) [New book about the Finnish question (Hermanson R. On the question of the situation in Finland. Helsingfors, 1909)]. Avtor A. V. Finlyandiya. 1910. 10: 377-382.

20. Novikova I. 2014. «Porokhovoy sklad», «priton dlya revolyutsionerov», «platsdarm dlya terroristov»: obraz Finlyandii v rossiyskoy natsionalisticheskoy pechati (vtoraya polovina XIX - nachalo KhKh v.) [«Powder warehouse», «a den for revolutionaries», «a springboard for terrorists»: the image of Finland in the Russian nationalist press (second half of the 19th - early 20th century). Finland and Russia: images of the shared past: a collection of scientific articles]. Finlyandiya i Rossiya: obrazy obshchego proshlogo: Finland and Russia: images of the shared past: sbornik nauchnykh statey. Mezhdistsiplinarnyy Nauchno-obrazovatel'nyy tsentr pribaltiysko-finskikh issled. FENNICA; sost. i nauch. red.: I.R. Takala, A.V. Tolstikov. Petrozavodsk, Izd-vo PetrGU, 2014: 189-198.

21. Nyugol'm K.V. 1901. Polozhenie Finlyandii v Rossiyskoy derzhave [The position of Finland in the Russian state]. Berlin: kn. mag. Shtura (vladelets I. Rede), 1901. VI, [2]: 125.

22. Ossio Yu. 2009 Velikoe knyazhestvo Finlyandskoe 1809-1917 [Grand Duchy of Finland 1809-1917. Translation from Finnish]. Perevod s finskogo yazyka. Khel'sinki: Ruslania Books Oy, 2009, 860.

23. Pogodin A.L. 1909. Finlyandiya i Pol'sha [Finland and Poland]. Finlyandiya. 5 (23): 13-16. 
24. Renvall P. 1969. Sem'sot let narodnogo predstavitel'stva v Finlyandii. Parlament Finlyandii [Seven hundred years of national representation in Finland. Parliament of Finland]. Poorvo-Khel'sinki: $14-15$

25. Oivo Nygård. 2003. Autonomian menetys. Itsenäisyyden sarastus. Teoksessa: Zetterberg, S. (toim.) Suomen historian pikkujättiläinen: 566-580.

26. Weeks Th.R. 1996. Nations and State in late Imperial Russia. Nationalism and russification on the Western Frontier, 1863-1914. DeKalb, Nothern Illinois University Press, 216.

Конфликт интересов: о потенциальном конфликте интересов не сообщалось.

Conflict of interest: no potential conflict of interest related to this article was reported.

\section{ИНФОРМАЦИЯ ОБ АВТОРАХ}

Карнишина Наталья Геннадьевна, доктор исторических наук, профессор кафедры История Отечества, государства и права Пензенского государственного университета, г. Пенза, Россия

Карнишин Валерий Юрьевич, доктор исторических наук, профессор, заведующий кафедрой История Отечества, государства и права Пензенского государственного университета, г. Пенза, Россия

\section{INFORMATION ABOUT THE AUTHORS}

Natalia G. Karnishina, Doctor of Historical Sciences, Professor of the Department of History of the Fatherland, State and Law, Penza State University, Penza, Russia

Valery Yu. Karnishin, Doctor of Historical Sciences, Professor, Head of the Department of History of the Fatherland, State and Law, Penza State University, Penza, Russia 